\title{
COMPARISON OF THE LEVEL OF AGGRESSION TOWARDS HEALTHCARE WORKERS WITHIN PODLASKIE VOIVODESHIP
}

\section{KRYSTYNA KOWALCZUK, BARBARA JANKOWIAK, ELŻBIETA KRAJEWSKA-KUŁAK, KATARZYNA VAN DAMME-OSTAPOWICZ, and BEATA KOWALEWSKA}

Medical University of Białystok, Białystok, Poland

Department of Health Sciences

\begin{abstract}
Objectives: The aim of this study was to estimate the level of exposure and average intensity of aggression towards particular professional groups of healthcare workers. Materials and Methods: Study participants $(n=1498)$ were employed at open and closed healthcare units within Podlaskie Voivodeship: 493 nurses, 504 midwives and 501 physicians. The MDM Questionnaire was applied. Results: Aggression originating from patients was experienced by $92 \%$ of nurses, $86 \%$ of doctors, and $74 \%$ of midwives examined. Aggressive behavior of co-working physicians concerned $55 \%$ of midwives, $54 \%$ of nurses and $40 \%$ of physicians. The highest average levels of patient aggression, ranging between 2.20 and 3.31, were reported by nurses. Conclusions: Nurses are the group most exposed to most aggression forms and sources. Physicians are least exposed to aggression, except for aggression manifested by patients.
\end{abstract}

Key words:

Aggression, Stress, Nurse, Midwife, Physician

\section{INTRODUCTION}

A crucial matter concerning the working environment is violence coming from the inside and/or outside of an organization. Violence inside the workplace, in relation to workers, superiors, and subordinates, seems to be more important than violence from the outside of an organization. Psychological violence is less obvious, and it is noticed by surrounding people and co-workers less frequently than physical aggression. Likewise, the aggressive behavior of strangers is immediately noticed, while the aggressive behavior of co-workers is often neglected, ignored, even treated as something embarrassing and as such, often concealed [1,2].
Disturbances in interpersonal communication are a part of the everyday work experience; sometimes, however, they take the form of belittling, ridiculing (verbal aggression) or hitting and pulling (physical aggression). Aggressive behaviors are often the consequence of suppressing long-lasting emotional states, physical and psychological overexertion, feelings of injustice, and the impossibility of fulfilling basic needs. Provocations often cause a negative return of aggression, while at the same time the aggressor frees himself from the responsibility for his behavior by justifying it with the previous acts of aggression [3-5]. Violence in the workplace is a complex, multifaceted phenomenon dependent on many factors, including cultural ones, organizational ones,

Received: February 23, 2011. Accepted: April 26, 2011.

Address reprint request to K. Kowalczuk, Department of Integrated Medical Care, Medical University of Białystok, M. Skłodowskiej-Curie 7A, 15-096 Białystok, Poland (e-mail: kkowalczuk@op.pl). 
and personalities. The most common form of aggressive behaviors is psychological violence - mobbing, sexual harassment, intimidation. It takes place as long as people are forced to spend time together for a particular period of time, for example in the workplace, or school setting [2,6-8].

Violence in the workplace does not only concern the involved individuals who experience physical injuries and long-lasting stress. It also influences the whole team as witnesses of mobbing who suffer the consequences of a particular situation. The level of work engagement and motivation decreases in a team exposed to such occurrences, which results in decreased levels of work efficiency. That being so, violence in the workplace also causes notable financial loses for both workers and organizations. At the same time, these occurrences lead to consequences which are then experienced by the whole society. Firstly, there are additional costs in the area of healthcare and social security as well as pension benefits for people experiencing violence. Secondly, the victims themselves and also those who witness aggressive behavior often experience weakening of their family and social relations. People who were subjected to violence consider it difficult to discuss it in public, however, the management of an organization marred with acts of aggression finds it even harder to admit to it, fearing that it may possibly besmirch the organization's good name or methods of its management. Due to the growing number of cases of violence in the workplace, especially in scope of that of psychological nature, finding efficient ways of counteracting violence has become an urgent need $[3,9,10]$.

The aim of this study was to estimate the level of exposure and average intensity of aggression towards particular professional groups of healthcare workers.

\section{MATERIALS AND METHODS}

The study was conducted in July 2009 after receiving permission from the local Bioethical Commission of the Medical University of Białystok (UMB R-I-002/24/2009).
The population of examined individuals consisted of 1498 people employed in open and closed healthcare units within Podlaskie Voivodeship. Respondents were divided into three groups in regard to their profession. The first group consisted of 493 nurses (32.9\%), the second comprised 504 midwives $(33.6 \%)$, and the third consisted of 501 physicians $(33.5 \%)$.

The MDM Questionnaire, developed at the Department of Occupational Psychology of the Nofer Institute of Occupational Medicine in Lodz, was applied. This questionnaire was developed in order to examine the frequency of aggression inside the workplace. It contains 56 questions (32 diagnostic questions and 24 additional ones) pertaining to various aggressive behaviors the respondents may experience at work from their superiors, co-workers and customers. The answers to these questions are graded using a six-point frequency scale where 0 corresponds to "never" and 5 - to "at least once a week" [11]. The results were presented in maximally condensed forms, often using means, which were applied in order to demonstrate the intensity of aggression among those people who were exposed to it.

Statistical analysis of the data demanded the use of descriptive methods and a correlation study for qualitative and quantitative variables by means of the chi-square and Kruskal-Wallis tests. Calculations were performed using the Statistica 7 (StatSoft ${ }^{\circledR}$, Poland) package, with statistical significance defined as $\mathrm{p} \leq 0.05$.

\section{RESULTS}

Both nurses (97.6\%) and midwives (99.6\%) were mainly represented by women. The group of physicians was quite equal in terms of sex. Women accounted for $56.7 \%$ of the group. The age ranges in the populations compared showed great similarity. The only noticeable difference was the maximum age, which amounted to 70 years in the population of physicians, 
Table 1. Forms of aggression experienced by the study participants regardless of the source

\begin{tabular}{|c|c|c|c|c|c|c|c|}
\hline \multirow{2}{*}{ Aggression form } & \multicolumn{2}{|c|}{ Nurses } & \multicolumn{2}{|c|}{ Midwives } & \multicolumn{2}{|c|}{ Physicians } & \multirow{2}{*}{$\mathrm{p}$ value ${ }^{1}$} \\
\hline & $\mathrm{n}$ & $\%$ & $\mathrm{n}$ & $\%$ & $\mathrm{n}$ & $\%$ & \\
\hline Raised voice & 468 & $95^{*}$ & 423 & 84 & 432 & 86 & $<0.001$ \\
\hline Threats & 360 & $73^{* *}$ & 248 & 49 & 328 & $65^{*}$ & $<0.001$ \\
\hline Blackmail & 236 & $48^{* *}$ & 138 & 27 & 191 & $38^{*}$ & $<0.001$ \\
\hline Attempt to strike & 249 & $51^{*}$ & 88 & 17 & 110 & 22 & $<0.001$ \\
\hline Dangerous attitude & 357 & $72 * *$ & 213 & 42 & 288 & $57^{*}$ & $<0.001$ \\
\hline Vulgar behavior in the presence of co-workers & 381 & $77^{* *}$ & 260 & 52 & 313 & $62^{*}$ & $<0.001$ \\
\hline Vulgar behavior in the presence of patients & 368 & $75^{* *}$ & 234 & 46 & 288 & $57^{*}$ & $<0.001$ \\
\hline Attack, strike & 139 & $28^{*}$ & 69 & 14 & 50 & 10 & $<0.001$ \\
\hline
\end{tabular}

${ }^{1}$ Chi-square test.

*,** Significant differences of distributions.

while in the remaining populations, it was 56 and 57 years, respectively.

In respondent self-evaluation, the most common form of aggression was "using a raised voice". Significant differences in the distribution of various aggression forms were observed amongst the professional groups analyzed (Table 1). Respondents were most often exposed to aggressive behaviors on the patients' part. Also in this aspect, significant differences in the distribution of various aggression sources were observed amongst the analyzed professions (Table 2). Using a raised voice was the most frequent form of aggression irrespective of its source (depending on a profession and source, reported by $19 \%$ to $89 \%$ of the medical personnel examined). The average intensity of this form of aggression, for the individual groups within the population examined, ranged from 2.21 to 3.31 implying that the respondents experienced verbal aggression from patients and their colleagues at least several times a month. Significant differences in the distribution of various aggression forms were observed amongst the professional groups analyzed, with nurses being the group most exposed to most aggression forms and sources. Physicians were least exposed to aggression, except for aggression on the patients' part (Tables 3-7).

Table 2. Sources of aggression experienced by the study participants regardless of the form

\begin{tabular}{lcccccccr}
\hline & \multirow{2}{*}{ Sources of aggression } & \multicolumn{2}{c}{ Nurses } & \multicolumn{2}{c}{ Midwives } & \multicolumn{2}{c}{ Physicians } & \multirow{2}{*}{ p value $^{1}$} \\
\cline { 2 - 6 } \multicolumn{1}{c}{} & $\mathrm{n}$ & $\%$ & $\mathrm{n}$ & $\%$ & $\mathrm{n}$ & $\%$ & & \\
\hline Patients & 456 & $92^{* *}$ & 372 & 74 & 433 & $86^{*}$ & $<0.001$ \\
Superiors & 215 & $44^{*}$ & 235 & $47^{*}$ & 179 & 36 & 0.002 \\
Doctors & 268 & $54^{*}$ & 277 & $55^{*}$ & 199 & 40 & $<0.001$ \\
Nurses/Midwives & 246 & $50^{* *}$ & 216 & $43^{*}$ & 121 & 24 & $<0.001$ \\
Subordinates & 181 & $37^{* *}$ & 119 & $24^{*}$ & 86 & 17 & $<0.001$ \\
\hline
\end{tabular}

Abbreviations as in Table 1. 
Table 3. Forms and intensity of aggression on the patients' part experienced by the study participants

\begin{tabular}{|c|c|c|c|c|c|c|c|c|c|c|c|}
\hline \multirow{2}{*}{ Aggression form } & \multicolumn{3}{|c|}{ Nurses } & \multicolumn{3}{|c|}{ Midwives } & \multicolumn{3}{|c|}{ Physicians } & \multirow{2}{*}{$\mathrm{p}$ value $^{1}$} & \multirow{2}{*}{ p value } \\
\hline & $\mathrm{n}$ & $\%$ & mean & $\mathrm{n}$ & $\%$ & mean & $\mathrm{n}$ & $\%$ & mean & & \\
\hline Raised voice & 440 & $89 * *$ & $3.31^{\# \#}$ & 353 & 70 & 2.65 & 411 & $82 *$ & $2.92^{\#}$ & $<0.001$ & $<0.001$ \\
\hline Threats & 328 & $67^{*}$ & $2.77^{\#}$ & 176 & 35 & 2.53 & 306 & $61^{*}$ & 2.54 & $<0.001$ & $<0.001$ \\
\hline Blackmail & 197 & $40^{* *}$ & $2.58^{\#}$ & 88 & 17 & $2.73^{\# \#}$ & 168 & $34^{*}$ & 2.49 & $<0.001$ & 0.169 \\
\hline Attempt to strike & 238 & $48^{* *}$ & 2.49 & 63 & 13 & $2.83^{\#}$ & 104 & $21^{*}$ & 2.53 & $<0.001$ & 0.030 \\
\hline Dangerous attitude & 326 & $66^{* *}$ & $2.60^{\#}$ & 153 & 30 & 2.46 & 255 & $51^{*}$ & 2.51 & $<0.001$ & 0.005 \\
\hline $\begin{array}{l}\text { Vulgar behavior in the presence } \\
\text { of co-workers }\end{array}$ & 343 & $70^{* *}$ & $2.90^{\# \#}$ & 182 & 36 & 2.47 & 282 & $56^{*}$ & $2.57^{\#}$ & $<0.001$ & $<0.001$ \\
\hline Vulgar behavior in the presence of patients & 340 & $69^{* *}$ & $2.87^{\#}$ & 158 & 31 & 2.53 & 264 & $53^{*}$ & 2.55 & $<0.001$ & $<0.001$ \\
\hline Attack, strike & 129 & $26^{*}$ & 2.20 & 45 & 9 & $3.00^{\# \#}$ & 45 & 9 & $2.60^{\#}$ & $<0.001$ & $<0.001$ \\
\hline
\end{tabular}

${ }^{1}$ Chi-square test. ${ }^{2}$ Kruskal-Wallis test.

*,** Significant differences of distributions.

\#,\# Significant differences of mean values.

Table 4. Forms and intensity of aggression on the superiors' part experienced by the study participants

\begin{tabular}{|c|c|c|c|c|c|c|c|c|c|c|c|}
\hline \multirow{2}{*}{ Aggression form } & \multicolumn{3}{|c|}{ Nurses } & \multicolumn{3}{|c|}{ Midwives } & \multicolumn{3}{|c|}{ Physicians } & \multirow{2}{*}{$\mathrm{p}$ value $^{1}$} & \multirow{2}{*}{ p value } \\
\hline & $\mathrm{n}$ & $\%$ & mean & $\mathrm{n}$ & $\%$ & mean & $\mathrm{n}$ & $\%$ & mean & & \\
\hline Raised voice & 188 & $38^{*}$ & 2.51 & 199 & $39 *$ & 2.55 & 149 & 30 & 2.40 & 0.002 & 0.340 \\
\hline Threats & 94 & $19^{*}$ & 2.50 & 103 & $20^{*}$ & 2.65 & 66 & 13 & 2.59 & 0.006 & 0.569 \\
\hline Blackmail & 48 & 10 & 2.63 & 63 & 13 & 2.63 & 40 & 8 & 2.65 & 0.057 & 0.991 \\
\hline Attempt to strike & 5 & 1 & 2.40 & 20 & $4^{*}$ & 2.75 & 4 & 1 & 2.50 & 0.001 & 0.788 \\
\hline Dangerous attitude & 52 & 11 & 2.71 & 85 & $17^{*}$ & 2.84 & 54 & 11 & 2.57 & 0.003 & 0.661 \\
\hline $\begin{array}{l}\text { Vulgar behavior in the presence } \\
\text { of co-workers }\end{array}$ & 108 & $22^{*}$ & 2.65 & 110 & $22^{*}$ & 2.80 & 69 & 14 & 2.67 & 0.001 & 0.391 \\
\hline Vulgar behavior in the presence of patients & 90 & $18^{*}$ & 2.64 & 100 & $20^{*}$ & 2.80 & 46 & 9 & 2.83 & $<0.001$ & 0.484 \\
\hline Attack, strike & 5 & 1 & 3.00 & 21 & $4^{*}$ & 2.81 & 2 & 0 & 3.50 & $<0.001$ & 0.508 \\
\hline
\end{tabular}

${ }^{1}$ Chi-square test. ${ }^{2}$ Kruskal-Wallis test.

**** Significant differences of distributions.

Table 5. Forms and intensity of aggression on the physicians' part experienced by the study participants

\begin{tabular}{|c|c|c|c|c|c|c|c|c|c|c|c|}
\hline \multirow{2}{*}{ Aggression form } & \multicolumn{3}{|c|}{ Nurses } & \multicolumn{3}{|c|}{ Midwives } & \multicolumn{3}{|c|}{ Physicians } & \multirow{2}{*}{$\mathrm{p}$ value $^{1}$} & \multirow{2}{*}{$\mathrm{p}$ value } \\
\hline & $\mathrm{n}$ & $\%$ & mean & $\mathrm{n}$ & $\%$ & mean & $\mathrm{n}$ & $\%$ & mean & & \\
\hline Raised voice & 254 & $52^{*}$ & 2.37 & 244 & $48^{*}$ & 2.48 & 173 & 35 & 2.32 & $<0.001$ & 0.068 \\
\hline Threats & 90 & $18^{*}$ & 2.38 & 89 & $18^{*}$ & 2.66 & 61 & 12 & 2.57 & 0.016 & 0.113 \\
\hline Blackmail & 38 & 8 & 2.61 & 55 & $11^{*}$ & 2.71 & 33 & 7 & 2.70 & 0.037 & 0.844 \\
\hline Attempt to strike & 7 & 1 & 3.00 & 23 & $5^{*}$ & 2.83 & 9 & 2 & 3.22 & 0.003 & 0.780 \\
\hline Dangerous attitude & 50 & 10 & 2.78 & 84 & $17^{*}$ & 2.70 & 53 & 11 & 2.57 & 0.002 & 0.613 \\
\hline
\end{tabular}


Table 5. Forms and intensity of aggression on the physicians' part experienced by the study participants - cont.

\begin{tabular}{|c|c|c|c|c|c|c|c|c|c|c|c|}
\hline \multirow{2}{*}{ Aggression form } & \multicolumn{3}{|c|}{ Nurses } & \multicolumn{3}{|c|}{ Midwives } & \multicolumn{3}{|c|}{ Physicians } & \multirow{2}{*}{ p value ${ }^{1}$} & \multirow{2}{*}{$\mathrm{p}$ value ${ }^{2}$} \\
\hline & $\mathrm{n}$ & $\%$ & mean & $\mathrm{n}$ & $\%$ & mean & $\mathrm{n}$ & $\%$ & mean & & \\
\hline $\begin{array}{l}\text { Vulgar behavior in the presence } \\
\text { of co-workers }\end{array}$ & 125 & $25^{*}$ & 2.45 & 115 & $23^{*}$ & 2.65 & 74 & 15 & 2.45 & $<0.001$ & 0.167 \\
\hline Vulgar behavior in the presence of patients & 113 & $23^{*}$ & 2.40 & 99 & $20^{*}$ & 2.72 & 53 & 11 & 2.55 & $<0.001$ & 0.063 \\
\hline Attack, strike & 9 & 2 & 2.56 & 23 & $5^{*}$ & 2.83 & 3 & 1 & 2.67 & $<0.001$ & 0.752 \\
\hline
\end{tabular}

Abbreviations as in Table 4.

Table 6. Forms and intensity of aggression on the nurses' and midwives' part experienced by the study participants

\begin{tabular}{|c|c|c|c|c|c|c|c|c|c|c|c|}
\hline \multirow{2}{*}{ Aggression form } & \multicolumn{3}{|c|}{ Nurses } & \multicolumn{3}{|c|}{ Midwives } & \multicolumn{3}{|c|}{ Physicians } & \multirow{2}{*}{$\mathrm{p}$ value $^{1}$} & \multirow{2}{*}{ p value } \\
\hline & $\mathrm{n}$ & $\%$ & mean & $\mathrm{n}$ & $\%$ & mean & $\mathrm{n}$ & $\%$ & mean & & \\
\hline Raised voice & 225 & $46^{* *}$ & 2.35 & 196 & $39^{*}$ & 2.45 & 95 & 19 & 2.36 & $<0.001$ & 0.621 \\
\hline Threats & 81 & $16^{*}$ & 2.43 & 81 & $16^{*}$ & $2.79^{\#}$ & 30 & 6 & $2.83^{\#}$ & $<0.001$ & 0.018 \\
\hline Blackmail & 41 & $8^{*}$ & 2.73 & 52 & $10^{*}$ & 2.77 & 20 & 4 & 2.85 & 0.001 & 0.999 \\
\hline Attempt to strike & 9 & 2 & 3.33 & 22 & $4^{*}$ & 2.77 & 6 & 1 & 2.50 & 0.003 & 0.402 \\
\hline Dangerous attitude & 40 & 8 & 2.63 & 52 & 10 & 3.08 & 42 & 8 & 2.79 & 0.411 & 0.152 \\
\hline $\begin{array}{l}\text { Vulgar behavior in the presence } \\
\text { of co-workers }\end{array}$ & 111 & $23^{* *}$ & 2.41 & 82 & $16^{*}$ & 2.72 & 48 & 10 & 2.60 & $<0.001$ & 0.176 \\
\hline Vulgar behavior in the presence of patients & 73 & $15^{*}$ & 2.47 & 68 & $13^{*}$ & 2.85 & 34 & 7 & 2.74 & $<0.001$ & 0.054 \\
\hline Attack, strike & 8 & $2^{*}$ & 3.25 & 25 & $5 * *$ & 2.96 & 2 & 0 & 3.00 & $<0.001$ & 0.807 \\
\hline
\end{tabular}

${ }^{1}$ Chi-square test. ${ }^{2}$ Kruskal-Wallis test.

$*, * *$ Significant differences of distributions.

\# Significant difference of mean value.

Table 7. Forms and intensity of aggression on the subordinates' part experienced by the study participants.

\begin{tabular}{|c|c|c|c|c|c|c|c|c|c|c|c|}
\hline \multirow{2}{*}{ Aggression form } & \multicolumn{3}{|c|}{ Nurses } & \multicolumn{3}{|c|}{ Midwives } & \multicolumn{3}{|c|}{ Physicians } & \multirow{2}{*}{$\mathrm{p}$ value ${ }^{1}$} & \multirow{2}{*}{ p value } \\
\hline & $\mathrm{n}$ & $\%$ & mean & $\mathrm{n}$ & $\%$ & mean & $\mathrm{n}$ & $\%$ & mean & & \\
\hline Raised voice & 165 & $33^{* *}$ & $2.53^{\# \#}$ & 96 & $19^{*}$ & $2.45^{\# \#}$ & 57 & 11 & 2.21 & $<0.001$ & 0.006 \\
\hline Threats & 76 & $15^{* *}$ & 2.63 & 51 & $10^{*}$ & 2.65 & 25 & 5 & 2.40 & $<0.001$ & 0.193 \\
\hline Blackmail & 35 & $7^{*}$ & 2.71 & 31 & $6^{*}$ & 2.87 & 8 & 2 & 3.00 & $<0.001$ & 0.884 \\
\hline Attempt to strike & 16 & $3^{*}$ & 2.88 & 20 & $4^{*}$ & 2.95 & 4 & 1 & 2.75 & 0.005 & 0.922 \\
\hline Dangerous attitude & 47 & 10 & 2.53 & 41 & 8 & $3.29^{\# \#}$ & 30 & 6 & $2.80^{\# \#}$ & 0.112 & 0.002 \\
\hline $\begin{array}{l}\text { Vulgar behavior in the presence } \\
\text { of co-workers }\end{array}$ & 91 & $18^{* *}$ & 2.68 & 54 & $11^{*}$ & 3.06 & 33 & 7 & 2.52 & $<0.001$ & 0.037 \\
\hline Vulgar behavior in the presence of patients & 77 & $16^{* *}$ & 2.53 & 50 & $10^{*}$ & $3.00^{\# \#}$ & 27 & 5 & 2.52 & $<0.001$ & 0.025 \\
\hline Attack, strike & 9 & 2 & 2.56 & 22 & $4^{*}$ & 2.86 & 4 & 1 & 2.50 & 0.001 & 0.486 \\
\hline
\end{tabular}

Abbreviations as in Table 3. 


\section{DISCUSSION}

Studies concerning the mechanisms of aggression, conducted for many years, show the complexity of the problem. As science and diagnostic techniques develop, new theories regarding this matter are continuing to emerge. These theories are based on psychological knowledge as well as biochemical phenomena analysis. There is not much data concerning exposure to aggression in the workplace in Poland [12-13]. However, on the basis of our study, it appears that $96 \%$ of nurses, $90 \%$ of physicians and $86 \%$ of midwives were exposed to aggressive behaviors regardless of their source and form, at least once a year. The group most exposed to aggression in the workplace was the group of nurses.

A study conducted by Quine [18] confirmed that aggressive behavior in the workplace on the patients' part, as well as on the co-workers' part, concerns precisely nurses and is the reason for professional destabilization (33\%), victim separation (27\%), and an affront to somebody's personal dignity (22\%). In our study, it was demonstrated that patients made threats towards $67 \%$ of nurses, $61 \%$ of physicians and $35 \%$ of midwives. The results of studies carried out in Colorado demonstrated that $30 \%$ of nurses experienced violence in the workplace during the period of one year $[18,19]$.

The outcome of our study is similar to the data obtained in the North America in the group of physicians working in the open healthcare [20]. According to this study, the most common form of violence in the workplace was verbal aggression on the patients' part (74.95\%) and physical attack $(11.7 \%)$. Acts of aggression of threatening nature were more commonly experienced by female physicians (95\%) working in open healthcare systems [20]. The research conducted among adults from the United States, holding different positions in an organization, showed that $7 \%$ of workers experienced threats in the workplace and $19 \%$ of them experienced psychological harassment. The majority of the ensuing acts of aggression were not noted in the official statistics [14]. The results of a study conducted in Australian general hospitals over a period of five months revealed 68 incidents of aggression manifested by patients. The majority of them took place on night and afternoon shifts due to a limited number of staff. The strategies employed in order to calm down the aggressive patients were mainly based on the application of pharmacotherapy or physical restraints [18,20].

Our study revealed that threats on the superiors' part were made towards $20 \%$ of midwives, $19 \%$ of nurses and $13 \%$ of physicians. In Australia, a study concerning a group of healthcare workers showed that $50 \%$ of the respondents were exposed to acts of aggression from the outside of an organization while performing their professional duties; $46 \%$ of the respondents experienced violence on the superiors' and co-workers' part [21].

In our study, aggressive behavior of physicians, meaning „threats," took place towards $18 \%$ of nurses and midwives and $12 \%$ of colleagues-physicians. Lenartowicz [22] sees the causes of conflicts between nurses and physicians in the fact that nurses are always treated as auxiliary staff, appointed to carrying out orders. He also claims that throughout the years a feeling of inferiority of a nurse towards a physician was effectively consolidated and the opinion on lesser value of nursery in comparison to medical sciences [22] was formed.

In our research, it was also shown that $16 \%$ of nurses and midwives used threats towards the members of their own professional group, and $6 \%$ of them made threats towards physicians. The results obtained by Rowe et al. [23] showed that nurses often experienced verbal aggression on their colleagues' part (80\%), and on their superiors' part $(20 \%)$. The nurses who experienced verbal aggression regularly felt more stressed, less satisfied with their work, were more often on sick leave, and paid less attention to their patients [23].

In order to stop the violence, many countries in Europe, as well as the United States, Canada and Australia, rely on 
special research programs called task forces. The aim of these task forces is to find optimal ways of violence prevention. Those projects are supposed to limit the risk of violence in the workplace [24]. The basic premise, aimed at workers protection common to all interventions, is a conviction that multidimensional approach towards the problem of eliminating the factors harmful to man's health and conduct is necessary.

In conclusion, this study revealed that the group most exposed to aggression, regardless of its form, was constituted by nurses, and the one least exposed to it was formed by midwives. In addition, it demonstrated that doctors are least exposed to aggression, regardless of its source, except for aggression on the patients' part. The highest values of average intensity of aggression, irrespective of its form and source, appear in the midwives group, the lowest values were obtained among nurses. The exception was exposure to aggression on the patients' part where the highest values were obtained among nurses, and the lowest values among midwives.

\section{REFERENCES}

1. Bączyk G, Poniedziałek M, Skokowska B. The level of preoperative anxiety of patients treated surgically. Pieleg Pol 2005;1(19):42-5 [in Polish].

2. Bechowska-Gebhardt A, Stalewski T. Mobbing. Pathology of staff management. Warszawa: Difin; 2004. p. 84 [in Polish].

3. European Parliament. On harassment at the workplace. Committee on Employment and Social Affairs, 2001/2339 (INI).

4. Hoel H, Sparks K, Cooper CL. The cost of violence/stress at work and the benefits of a violence/stress-free working environment. Geneva: International Labour Organization; 2001. p. 81.

5. Grabowski P. Pathology of management. Mobbing - phenomenon of psychological violence at a workplace. Antidotum 2002;5:29-35 [in Polish].

6. Grzywa A. Traps of manipulation. Lublin: Wydawnictwo Czelej; 2006. p. 176 [in Polish].
7. Heim E. Job stressors and coping in health professions. Psychother Psychosom 1991;55(2-4):90-9.

8. Hirigoyen MF. Harassment at a workplace. Poznań: Wydawnictwo „W Drodze”; 2003. p. 328 [in Polish].

9. Jędrek G. Legal responsibility for the use of mobbing. Warszawa: Lexis Nexis; 2004. p. 350 [in Polish].

10. Fagan-Pryor EC, Haber LC, Dunlap D, Nall JL, Stanley G, Wolpert W. Patients' views of causes of aggression by patients and effective interventions. Psychiatr Serv 2003;54(4):549-53.

11. Dudek B, Waszkowska M, Merecz D, Hanke W. Worker's health protection against the consequences of occupational stress. Łódź: Instytut Medycyny Pracy; 2004 [in Polish].

12. Merecz D, Mościcka A. How to manage aggression at a workplace? Łódź: Instytut Medycyny Pracy; 2003 [in Polish].

13. Merecz D, Mościcka A. Violence at healthcare units and the ways of its prevention. Lódź; Instytut Medycyny Pracy; 2003 [in Polish].

14. Mościcka A, Merecz D. Workplace aggression: sources, forms, risk groups and consequences. Med Pr 2003;54(4): 361-8 [in Polish].

15. Merecz D, Mościcka A, Drabek M. Mobbing at a workplace. Consequences, legal aspects and preventive measures. Łódź: Instytut Medycyny Pracy; 2005 [in Polish].

16. Jankowiak B, Kowalczuk K, Krajewska-Kułak E, Sobolewski M, Sierakowska M, Lewko J. Endangerment the nurses on aggressions in place of work. Ann UMCS D 2006;60 (Suppl 16):458-63.

17. Kowalczuk K, Jankowiak B, Krajewska-Kułak E, Sierakowska M, Rolka H, Lewko J, Klimaszewska K, Ostapowicz-Van Damme K, Kondzior D. Mobbing in work of obstetrics. Pol J Environ Stud 2008;17(4B):338-42.

18. Quine L. Workplace bullying in NHS community trust: staff questionnaire survey. BMJ 1999;318(7178):228-32.

19. Kowalenko T, Walters BL, Khare RK, Compton S; Michigan College Of Emergency Physicians Workplace Violence Task Force. Workplace violence: a survey of emergency physicians in the state of Michigan. Ann Emerg Med 2005;46(2):142-7. 
20. Roberts GL, Raphael B, Lawrence JM, O’Toole B, O'Brien D. Impact of an education program about domestic violence on nurses and doctors in an Australian emergency department. J Emerg Nurs 1997;23(3):220-7.

21. Needham I, Abderhalden C, Halfens RJ, Dassen T, Haug HJ, Fischer JE. The impact of patient aggression on Careers Scale: instrument derivation and psychometric testing. Scand J Caring Sci 2005;19(3):296-300.

22. Lenartowicz H. Political strategy of nursing. Pieleggniarstwo 2000 2000;4:9 [in Polish].
23. Rowe MM, Sherlock H. Stress and verbal abuse in nursing: do burned out nurses eat their young? J Nurs Manag 2005;13(3):242-8.

24. de Barbaro B, Izdebski R, Szwajca K, Treger B, Szaszkiewicz W. Revealing new context of violence in therapeutic work with families (from label to description). Przegl Lek 2004;11(61):1275-8 [in Polish].

This work is available in Open Access model and licensed under a Creative Commons Attribution-NonCommercial 3.0 Poland License - http://creativecommons.org/ licenses/by-nc/3.0/pl/deed.en. 